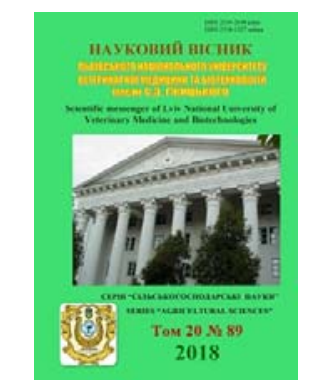

Науковий вісник Дьвівського національного університету ветеринарної медицини та біотехнологій імені С.З. Гжицького

\author{
Scientific Messenger of Lviv National University \\ of Veterinary Medicine and Biotechnologies
}

doi: $10.32718 /$ nvlvet8902 http://nvlvet.com.ua/

UDC 636.2.034

\title{
Features of milk productivity of cows of Ukrainian brown dairy breed and the influence of genotypical and paratypical factors on its formation
}

\author{
Y.I. Sklyarenko \\ Institute of Agriculture of Northern East of NAAS, Sumy district, Sad, Ukraine
}

Article info

Received 29.08.2018 Received in revised form 25.09 .2018 Accepted 26.09.2018

Institute of Agriculture of Northern East of NAAS, Zelena Str., 1, Sad, Sumy district, Sumy region, 42343, Ukraine.

Tel.: +38-095-131-09-31 E-mail: sklyrenko9753@ukr.net
Sklyarenko, Y.I. (2018). Features of milk productivity of cows of Ukrainian brown dairy breed and the influence of genotypical and paratypical factors on its formation. Scientific Messenger of Lviv National University of Veterinary Medicine and Biotechnologies, 20(89), 8-16. doi: $10.32718 /$ nvlvet8902

The indicators of milk productivity of cows of Ukrainian brown dairy breed were studied. The research was carried out on the basis of breeding farms of animal breeding of this breed by assessing the data of primary zootechnical accounting. It is established that the level of milk productivity of cows meets the breed standard and is within 4.5 thousand $\mathrm{kg}$ of milk. A significant correlation between the indicators of milk productivity and reproductive capacity was found. Milk productivity is negatively correlated with the main indicators of reproductive ability. The influence of genetic and paratypic factors on the formation of milk productivity was studied. It is established that a conditional bloodedness, linear membership and origin in the father significantly affects the level of milk productivity of cows. The impact of genetic factors increases from conditional crow nest of Swiss breed to descent on the father. Animals with the highest proportion of Swiss breed were significantly dominated by other animals by the milk yield per the first lactation. The highest milk yield in the first lactation were obtained from the animal of Vigate 083352 line and the smallest of Payvan 136140 line. By the greater amount of milk fat and protein, the animals of the Vigate 083352 line also prevailed. Animals from different bulls for the first lactation had milk yield in the range of 2780 $4464 \mathrm{~kg}$ of milk, the amount of milk fat and protein, respectively, 103-176 kg and 89-134 kg. A big impact on the economy of milk production having a term of economic use of animals. Therefore, in our view longevity as a symptom of dairy cows is an important selection basis. The significant influence of genotypic factors on the indicators of the duration of use and lifetime productivity of cows was established. The greatest impact of the paratypical factors had the farm, which contains animals. The conditions of keeping and feeding in the farm had a significant impact on the duration of use and lifetime productivity of cows. The presence of significant influence of genotypic and paratypical factors on the milk productivity of animals makes it possible to improve its breeding and technological activities.

Key words: breed, milk productivity, correlation, line, bloodline, genotypic factors, paratypical factors.

\section{Особливості молочної продуктивності корів української бурої молочної породи та вплив генотипових і паратипових факторів на її формування}

\author{
Ю.І. Скляренко
}

Інститут сільського господарства Північного Сходу НААН, с. Сад, Сумський район, Украӥна

\footnotetext{
Вивчені показники молочної продуктивності корів української бурої молочної породи. Дослідження проведені на базі племінних господарств з розведення тварин иієї породи шляхом оцінки даних первинного зоотехнічного обліку. Встановлено, що рівень молочної продуктивності корів відповідає стандарту породи і знаходиться в межах 4,5 тис. кг молока. Виявлений достовірний кореляиійний зв'язок між показниками молочної продуктивності та відтворної здатності. Молочна продуктивність негативно корелює з основними показниками відтворної здатності. Вивчений вплив генетичних та паратипових факторів на формування молочної продуктивності. Встановлено, що умовна кровність, лінійна належність і походження за батьком вірогідно виливає на рівень молочної продуктивності корів. Величина сили впливу генотипових факторів зростає від умовної кровності за швіцькою породою до походження за батьком. Тварини з найбільшою часткою за швіџькою породою достовірно переважали інших тварин за надоєм першої лактаиії. Найвищою молочною продуктивністю за першу лактачію відрізнялися тварини лінії Вігате 083352, а найменшою - Пейвена 136140. За більшою кількістю молочного жиру та білка також відрізнялися тварини лінії Вігате 083352. Тварини від
} 
різних бугаӥв-плідників за першу лактачію мали надій в межах 2780-4464 кг молока, кількість молочного жиру та білка відповідно 103-176 кг та 89-134 кг. Великий вплив на економіку виробнищтва молока надає термін господарського використання тварин. Тому на нашу думку довголіття, як ознака молочних корів, є важливою селекційною ознакою. Встановлений достовірний вплив генотипових факторів на показники тривалості використання та довічної продуктивності корів. 3 паратипових чинників, найбільший вплив мало господарство, в якому утримуються тварини. Умови утримання та годівлі в господарстві суттєво впливали на тривалість використання та довічну продуктивність корів. Наявність достовірного впливу генотипових та паратипових факторів на молочну продуктивність тварин, дає змогу поліпшити ї̈ селекиійними та технологічними заходами.

Ключові слова: порода, молочна продуктивність, кореляція, лінія, кровність, генотипові фактори, паратипові фактори.

\section{Вступ}

На сучасному етапі економічного розвитку молочне скотарство, щоб бути конкурентоспроможним i рентабельним, має грунтуватися на високопродуктивне поголів'я тварин. Молочне скотарство було і залишається однією 3 основних галузей сільського господарства. Значення галузі визначається не тільки їі високою часткою у виробництві валової продукції сільського господарства, в тому числі - тваринництва, а й великим соціальним впливом - молочне скотарство дає цілорічну зайнятість і стабільний дохід (Martens and Bange, 2013; Lobodna, 2014).

Висока молочна продуктивність корів визначається двома основними факторами: генетичним потенціалом і повноцінною годівлею. Найважливіше завдання розведення і селекції молочної худоби полягає в розведенні більш високопродуктивних корів, підвищенні ефективності селекції та інтенсифікації виробництва молока. У зв'язку з цим, поліпшення умов, що впливають на виробництва молока, відтворення, охорону здоров'я, розведення, годівлі, доїння, гігієни є важливим (Salohub, 2001; Babii, 2008; Khmelnychyi, 2012; De Vries, 2013; Gajdarska, 2015; Tsuruta et al., 2017).

Поліпшення продуктивних якостей тварин українських молочних порід здійснюється за допомогою поглинального схрещування 3 плідниками голштинської та швіцької порід різних країн світу. За повідомленнями багатьох дослідників, така односпрямована селекція призвела до погіршення рівня відтворення, продуктивного довголіття, якості продукції, загального здоров'я тварин тощо. Наразі вітчизняними науковцями ведеться пошук шляхів виправлення цієї ситуації. Зокрема для поліпшення низки економічно важливих селекційних ознак у тварин, провідними вченими-селекціонерами країни, враховуючи світовий досвід, пропонується схрещувати голштинську і створених за піi участі вітчизняних молочних порід 3 неспорідненими сучасними заводськими породами європейської та північноамериканської селекції, що, на їхню думку, дозволить отримати генетичний ефект гетерозису у помісей першого покоління (VandeHaar et al., 2016; Hutchison et al., 2017; Tsuruta et al., 2017).

Проблема зниження продуктивного довголіття молочної худоби поширена й за кордоном. Так, середня тривалість продуктивного використання корів у Німеччині становить 2,5-3,0, у західній Канаді - 1,6, у США - 2,63 лактації, у Нідерландах - 1108 днів (Gaidarska et al., 2010; Effa et al., 2013; Murray, 2013; Polupan, 2014).

Пошук резервів підвищення молочної продуктивності та продуктивного довголіття тварин $є$ актуаль- ним питанням для вітчизняного та зарубіжного молочного тваринництва в зв'язку з скороченням термінів ï господарського використання в останні десятиліття (Gill, 2008; Compton et al., 2016; De Vries, 2017; Milostiviy et al., 2017). Особливої гостроти ця проблема набуває серед стад високопродуктивних корів, фізіологічні процеси яких перебувають на межі біологічних можливостей, часто межують 3 патологічним станом організму (Chebel et al., 2016). На думку ряду авторів (Lucy, 2000; VandeHaar et al., 2016; De Vries, 2017), така ситуація є негативним наслідком комерціалізації молочної худоби і односторонньої селекції в напрямку бажаних ознак, що супроводжується зниженням імунного статусу тварин, плодючості, скороченням періоду виробничого використання і погіршенням якості молока. Продуктивне довголіття корів $\epsilon$ досить складною інтегральною ознакою, яка визначається як генетичними факторами, так і середовищними. Серед перших істотно впливає лінійна належність батьків, що свідчать про можливість ефективного внутрішньолінійних розведення за умови чіткого дотримання системи добору, підбору і оцінки тварин за племінною цінністю (Polupan, 2014; VandeHaar et al., 2016; Hutchison et al., 2017). Тому дослідження, що проводяться в аспекті впливу генеалогічних формувань на показники молочної продуктивності, тривалості використання і довічною продуктивності молочної худоби є актуальними і мотивованими.

Ефективне ведення галузі молочного скотарства визначається результативністю якісного вдосконалення наявних масивів вітчизняної молочної худоби, яке базується на принципах: великомасштабної селекції, системного комплексного аналізу, генетикопопуляційного моніторингу, моделювання селекційних процесів і направлене на підвищення їх генетичного потенціалу (Bolhova, 2009; Bratushka, 2013; VandeHaar et al., 2016).

Кожна порода характеризується властивими їй біологічними, селекційно-генетичними та господарсько-корисними особливостями, які формуються в певних умовах середовища і обумовлені спадковістю тварин (Lucy, 2000; Bolhova, 2009; Boiko, 2012; Martens and Bange, 2013; Murray, 2013; Compton et al., 2016).

Бура молочна порода - це результат напруженої праці науковців та зоотехніків-селекціонерів господарств останні 35 років. Основний масив створений на основі лебединської худоби шляхом використання швіців у кращих племінних і товарних господарствах Сумської області. Тварини створеної породи добре пристосовані до природно-кліматичної зони та умов розведення. Подальша робота 3 породою спрямована на запровадження у визначених категоріях госпо- 
дарств системних елементів, які є основою підвищення господарсько-корисних ознак тварин (Gajdarska, 2015; Hutchison et al., 2017; Tsuruta et al., 2017).

Результатом породних перетворень стала апробація державною комісією в 2005 році та затвердження в 2009 році української бурої молочної породи.

Метою досліджень $є$ вивчення особливостей формування молочної продуктивності корів української бурої молочної породи. Для досягнення мети необхідно вирішити наступні завдання: дослідити рівень молочної продуктивності корів, взаємозв'язок молочної продуктивності корів та їх відтворної здатності, вплив генотипових та паротипових факторів на молочну продуктивність, рівень довічної продуктивності корів.

\section{Матеріал і методи досліджень}

Дослідження проведені на базі племінних господарств з розведення української бурої молочної породи $(\mathrm{n}=668)$. До вибірки залучено інформацію первинного зоотехнічного обліку (Система управління молочним скотарством “Орсек”) 3 господарств Сумської області (племінний завод Державного підприємства "Дослідне господарство Інституту сільського господарства Північного Сходу НААН" Сумського району, племінні репродуктори - Білопільська філія Державного підприємства “Укрліктрави” та Агрофірма "Вікторія" Білопільського району).

Показники відтворної здатності та молочної продуктивності досліджували за загальноприйнятими методиками. Розрахунок тривалості сервіс-періоду, міжотельного періоду, сухостійного періоду, значення коефіцієнта відтворної здатності та індексу плодючості проводили за загальноприйнятими методиками в зоотехнії (Ladyka, 1999).

Ретроспективний аналіз тривалості та ефективнос- ті довічного використання корів здійснювали за методикою Ю.П. Полупана (Polupan, 2014). Для оцінки тривалості та ефективності довічного використання по кожній досліджуваній корові враховували інформацію про дату народження, дату першого отелення, дату вибуття зі стада. По кожній лактації (включно 3 можливо незакінченою останньою) враховували іiі тривалість, надій та вихід молочного жиру та білка за всю лактацію. На підставі вищенаведених показників для кожної тварини вирахували тривалість життя, господарського використання і лактування, довічний надій, середній, довічний вихід молочного жиру та білка, середній надій на один день життя, на один день господарського використання. Коефіцієнт господарського використання (Кгв) обчислювали (для зручності - 3 вираженням у відсотках) за формулою пропонованою M.С. Пелехатим зі співавторами (Lobodna, 2014).

Силу впливу $\left(\eta^{2}\right)$ різних генотипових та паратипових чинників на основні господарськи корисні ознаки вивчали методом однофакторного дисперсійного комплексу через співвідношення факторіальної дисперсії до загальної за методиками Н.А. Плохинского на персональному комп'ютері з використанням програмного забезпечення Statistica 6.0.

\section{Результати та їх обговорення}

В результаті проведених досліджень встановлено, що рівень молочної продуктивності корів української бурої молочної породи повністю відповідав породним вимогам (табл. 1). За надоєм першої лактації тварини переважали стандарт породи на 14\%, за третю лактацію - на 7\%. За кількістю молочного жиру та білка відповідно за першу - на $18 \%$ та 9\%, за третю - на $10 \%$ та $1 \%$.

\section{Таблиця 1}

Рівень молочної продуктивності корів

\begin{tabular}{lcccc}
\hline \multirow{2}{*}{ Лактація } & \multicolumn{4}{c}{ Показники продуктивності } \\
\cline { 2 - 5 } & $\begin{array}{c}\text { тривалість лактації, } \\
\text { днів }\end{array}$ & \multirow{2}{*}{ надій, кг } & $\begin{array}{c}\text { кількість молочного } \\
\text { жиру, кг }\end{array}$ & $\begin{array}{c}\text { кількість молочного } \\
\text { білка, кг }\end{array}$ \\
\hline I $(\mathrm{n}=668)$ & $382,0 \pm 4,6$ & $3665 \pm 34,1$ & $144,4 \pm 1,4$ & $115,4 \pm 1,0$ \\
III $(\mathrm{n}=212)$ & $358,6 \pm 6,3$ & $4497 \pm 75,3$ & $177,4 \pm 3,1$ & $139,2 \pm 2,4$ \\
Краща $(\mathrm{n}=668)$ & $362,8 \pm 5,8$ & $4566 \pm 69,6$ & $179,1 \pm 2,9$ & $144,1 \pm 2,4$ \\
\hline
\end{tabular}

Тривалість лактацій, як першої так і третьої, перевищує стандартну величину - 305 днів, відповідно, на 77 днів та 54 дні. За кращу лактацію середній рівень продуктивності тварин дещо перевищив 4,5 тис. кг молока. Найвища продуктивність корів української бурої молочної породи спостерігалася у тварин п’ятої лактації - $4658 \pm 170$ кг.

Між надоєм та показниками відтворної здатності встановлений достовірний кореляційний зв'язок (табл. 2). Між такими показниками, як тривалість сервіс-періоду, міжотельного періоду він позитивний.

Тобто, зростання надою за лактацію призводило до зростання тривалості сервіс-періоду, а, відповідно, і міжотельного періоду. Відповідно, коефіцієнт відтворної здатності негативно корелював 3 величиною надою. Коефіцієнт кореляції між надоєм та індексом плодючості підтверджує, що зі зростанням величини надою у тварин відбувається зниження показників відтворної здатності. Тривалість сухостійного періоду негативно корелював з величиною надою. 
Таблиця 2

Зв'язок між надоєм та показниками відтворної здатності, $\mathrm{r} \pm \mathrm{m}_{\mathrm{r}}$

\begin{tabular}{lccccc}
\hline \multirow{2}{*}{ Лактація } & \multicolumn{4}{c}{ Показники відтворної здатності } \\
\cline { 2 - 6 } & сервіс-період & міжотельний період & сухостійний період & КВ3 & індекс плодючості \\
\hline I (n=365) & $0,306 \pm 0,04^{* * *}$ & $0,308 \pm 0,05^{* * *}$ & $-0,04 \pm 0,05$ & $-0,34 \pm 0,04^{* * *}$ & $-0,33 \pm 0,04^{* * *}$ \\
II (n=186) & $0,430 \pm 0,05^{* * *}$ & $0,430 \pm 0,06^{* * *}$ & $-0,19 \pm 0,07^{* *}$ & $-0,44 \pm 0,06^{* * *}$ & $-0,35 \pm 0,06^{* * *}$ \\
III $(\mathrm{n}=76)$ & $0,460 \pm 0,09^{* * *}$ & $0,450 \pm 0,09^{* * *}$ & $-0,31 \pm 0,11^{* *}$ & $-0,48 \pm 0,09^{* * *}$ & $-0,31 \pm 0,10^{* * *}$ \\
\hline
\end{tabular}

Генотипові фактори достовірно впливали на рівень молочної продуктивності корів за першу та третю лактації. За кращу лактацію достовірного впливу не встановлено. Лінійна належність достовірно впливала на показники молочної продуктивності за першу лактацію. Перший із генетичних чинників впливу - умовна кровність помісних за швіцькою породою корів, має достовірний вплив на рівень надою та кількість жиру та білка в молоці, що необхідно враховувати у селекційному процесі подальшого поліпшення породи за молочною продуктивністю. Рівень та достовірність сили впливу генетичних особливостей батька корів свідчить про те, що від плідників значною мірою залежить величина надою $\left(\eta^{2}{ }_{x}=26,6\right.$ та 25,6$)$, кількість молочного жиру $\left(\eta^{2}{ }_{x}=29,5\right.$ і 21,6$)$, кількість молочного білка $\left(\eta^{2}{ }_{x}=23,7\right.$ і 23,7$)$ тварин підконтрольних стад 3 розведення української бурої молочної породи (табл. 3).

\section{Таблиця 3}

Вплив генотипових факторів на рівень молочної продуктивності (n = 668)

\begin{tabular}{|c|c|c|c|}
\hline \multirow{2}{*}{ Генотипі фактори } & \multicolumn{3}{|c|}{ Показники продуктивності } \\
\hline & Надій & Кількість молочного жиру & Кількість молочного білка \\
\hline \multirow{6}{*}{ Умовна кровність } & & I лактація & \\
\hline & $3,1^{* * *}$ & $2,9 * * *$ & $3,8 * * *$ \\
\hline & & III лактація & \\
\hline & $8,2 * *$ & $7,3^{* *}$ & $5,9^{*}$ \\
\hline & & Краща лактація & \\
\hline & 4,3 & 3,7 & 4,1 \\
\hline \multirow{6}{*}{ Лінійна належність } & & I лактація & \\
\hline & $2,7 * *$ & $3,8^{* * *}$ & $4,5 * * *$ \\
\hline & & III лактація & \\
\hline & 1,3 & 1,0 & 2,3 \\
\hline & & Краща лактація & \\
\hline & 2,3 & 2,9 & 2,0 \\
\hline \multirow{6}{*}{ Походження за батьком } & & I лактація & \\
\hline & $26,6^{* * *}$ & $29,5 * * *$ & $23,7 * * *$ \\
\hline & & III лактація & \\
\hline & $25,6^{* * *}$ & $21,6^{* * *}$ & $23,7 * * *$ \\
\hline & & Краща лактація & \\
\hline & 10,8 & 11,3 & 10,4 \\
\hline
\end{tabular}

Найвищою молочною продуктивністю за першу лактацію відрізнялися тварини лінії Вігате 083352, а найменшою - Пейвена 136140. Причому, тварини останньої лінії достовірно поступалися всім іншим.
Корови лінії Пейвена 136140 достовірно поступалися за кількістю молочного жиру тваринам інших ліній (табл. 4).

Таблиця 4

Молочна продуктивність корів різної лінійної належності

\begin{tabular}{|c|c|c|c|c|c|c|}
\hline \multirow[b]{2}{*}{ Лінія } & \multicolumn{3}{|c|}{ Продуктивність за I лактацію } & \multicolumn{3}{|c|}{ Продуктивність за III лактацію } \\
\hline & надій, кг & $\begin{array}{c}\text { кількість молоч- } \\
\text { ного жиру, кг }\end{array}$ & $\begin{array}{l}\text { кількість моло- } \\
\text { чного білка, кг }\end{array}$ & надій, кг & $\begin{array}{l}\text { кількість молоч- } \\
\text { ного жиру, кг }\end{array}$ & $\begin{array}{c}\text { кількість молоч- } \\
\text { ного білка, кг }\end{array}$ \\
\hline $\begin{array}{l}\text { Вігата } \\
083352(\mathrm{n}=148)\end{array}$ & $3700 \pm 61,9$ & $147,7 \pm 2,6$ & $116,0 \pm 2,0$ & $4307 \pm 194,2$ & $170,8 \pm 7,8$ & $135,5 \pm 6,2$ \\
\hline $\begin{array}{l}\text { Дістинкшна } \\
159523 \text { (n = 124) }\end{array}$ & $3649 \pm 92,6$ & $142,3 \pm 3,8$ & $111,8 \pm 2,9$ & $4397 \pm 186,0$ & $171,6 \pm 7,7$ & $136,2 \pm 5,9$ \\
\hline $\begin{array}{l}\text { Елеганта } 148551 \\
(\mathrm{n}=270)\end{array}$ & $3617 \pm 60,1$ & $142,8 \pm 2,5$ & $115,6 \pm 1,8$ & $4120 \pm 139,0$ & $162,4 \pm 5,6$ & $126,7 \pm 4,4$ \\
\hline $\begin{array}{l}\text { Пейвена } 136140 \\
(\mathrm{n}=32)\end{array}$ & $2953 \pm 200,0$ & $111,3 \pm 7,8$ & $86,7 \pm 6,2$ & $3925 \pm 354,0$ & $155,3 \pm 15,5$ & $112,2 \pm 9,9$ \\
\hline $\begin{array}{l}\text { Стретча } 143612 \\
(\mathrm{n}=84)\end{array}$ & $3460 \pm 97,0$ & $135,4 \pm 3,8$ & $108,7 \pm 3,2$ & $4029 \pm 253,0$ & $158,2 \pm 10,3$ & $127,5 \pm 8,2$ \\
\hline
\end{tabular}


Більш суттєвий вплив на показники молочної продуктивності мало походження за батьком. Тварини від різних бугаїв-плідників за першу лактацію мали надій в межах 2780-4464 кг молока, кількість молочного жиру та білку відповідно 103-176 кг та 89 - 134 кг. За третю лактацію рівень надою знаходився в межах 3350-5582 кг, молочного жиру 133-216 кг, молочного білку - 104-169 кг.

Умовна кровність за швіцькою породою мала достовірний вплив на показники молочної продуктивності за першу та третю лактації. Кращий надій за першу лактацію мали тварини із умовною кровністю більше ніж 94\% за швіцькою породою (табл. 5).

\section{Таблиця 5}

Молочна продуктивність корів різної умовної кровності за швіцькою породою

\begin{tabular}{lcccccc}
\hline \multirow{2}{*}{$\begin{array}{c}\text { Умовна кровність, } \\
\text { \% }\end{array}$} & \multicolumn{3}{c}{ Продуктивність за І лактацію } & \multicolumn{3}{c}{ Продуктивність за ІІІ лактацію } \\
\cline { 2 - 7 } & надій, кг & кількість молоч- кількість молоч- & ного жиру, кг & ного білка, кг & най, кг & \multicolumn{2}{c}{ кількість молоч- кількість молоч- } \\
ного жиру, кг & ного білка, кг \\
\hline Менше 50 (n=96) & $3399 \pm 80,8$ & $133,9 \pm 3,3$ & $105,3 \pm 2,4$ & $4300 \pm 158,1$ & $170,8 \pm 6,7$ & $132,4 \pm 5,1$ \\
$50,1-75(\mathrm{n}=176)$ & $3779 \pm 75,2$ & $148,2 \pm 3,0$ & $119,6 \pm 2,0$ & $4905 \pm 152,0$ & $192,7 \pm 6,1$ & $149,3 \pm 4,7$ \\
$75,1-87,5(\mathrm{n}=279)$ & $3601 \pm 48,8$ & $141,8 \pm 2,0$ & $114,1 \pm 1,6$ & $4323 \pm 101,4$ & $170,8 \pm 4,2$ & $136,4 \pm 3,3$ \\
$87,6-94,5(\mathrm{n}=24)$ & $3757 \pm 151,2$ & $149,6 \pm 6,3$ & $118,1 \pm 5,0$ & $4825,0 \pm 316,0$ & $190,1 \pm 5,2$ & $153,7 \pm 10,8$ \\
Більше 94,5 (n=50) & $3977,6 \pm 132,1$ & $157,8 \pm 5,3$ & $122,8 \pm 4,0$ & $3760,5 \pm 247,2$ & $145,2 \pm 11,9$ & $117,9 \pm 8,7$ \\
\hline
\end{tabular}

Вони достовірно переважали тварин із умовною кровністю до 50\% та від 75 до $87,5 \%$ за швіцькою породою. За третьою лактацією перевагу мали тварини із умовною кровністю від 50 до 75\% та від 87,5 до 93,5\%. За кількістю молочного жиру та білка в молоці перевагу мали також ці тварини. Тобто, тварини високої кровності за даних умов утримання та годівлі переважають низькокровних тварин за надоєм за першу лактацію, але поступаються за надоєм за третю лактацію.

Важливим є припущення, що продуктивне довголіття корів відноситься до спадкових ознак і тому його тривалість залежить, у першу чергу, від генетич- них чинників: породи, методів підбору, кровності за поліпшуючою породою.

Нами встановлено, що генотипові чинники достовірно впливають на рівень показників тривалості використання та довічної продуктивності корів української бурої молочної породи. Найбільшу силу впливу на продуктивне довголіття корів мав фактор походження за батьком. Меншою силою впливу характеризуються умовна кровність та лінійна належність. Вони достовірно впливали на тривалість життя, господарського використання та величини надою за 1 день життя (табл. 6).

\section{Таблиця 6}

Вплив генотипових факторів на показники тривалості використання та довічної продуктивності корів, $\eta^{2}$ х

\begin{tabular}{lccc}
\hline \multicolumn{1}{c}{ Показники } & \multicolumn{2}{c}{ Генотипові факторі } \\
\cline { 2 - 3 } Тривалість, днів & умовна кровність лінійна належність & походження за батьком \\
життя & $2,7^{*}$ & $3,1^{* * *}$ & $26,0^{* * *}$ \\
господарського використання & $2,1^{*}$ & $1,6^{*}$ & $21,0^{* * *}$ \\
Коефіцієнт господарського використання & 1,3 & 0,3 & $16^{* * *}$ \\
Довічна продуктивність: & $1,6^{*}$ & 0,3 & $17,0^{* * *}$ \\
надій & 0,8 & 0,8 & $5,7^{*}$ \\
жир & 0,9 & 0,7 & $14,9^{* * *}$ \\
Молочний жир & $4,9^{* * *}$ & $8,8^{*}$ & $38,6^{* * *}$ \\
Надій за 1 день: & 1,0 & 1,1 & $14,2^{* * *}$ \\
життя & & & \\
господарського використання & &
\end{tabular}

Результати ретроспективного аналізу засвідчили достовірний вплив умовної кровності швіцької породи на показники тривалості життя, господарського використання та довічної продуктивності корів української бурої молочної породи. Найкращими серед усіх груп тварин за показниками тривалості життя, господарського використання та коефіцієнту господарського використання виявилися помісні генотипи: групи тварин з умовною кровністю швіцької породи до 50\%. За показниками довічного надою та виходу молочного жиру і надою за один день життя вияви- лися тварини з умовною спадковістю швіцької породи від 75,1 до $87,5 \%$.

Умови утримання в певному господарстві мають також суттєвий вплив на рівень молочної продуктивності корів. Так, на сезон першого отелення, як на фактор що визначає рівень надою за першу лактацію, припадає $1,4 \%$. На кількість молочного жиру та білку впливу сезону першого отелення не встановлено (табл. 7).

Найвищий надій мали тварини, які отелилися вперше взимку. Вони достовірно переважали первісток 
весняного та літнього отелень на 7\% (P < 0,01) (табл. 8).

Жива маса при першому отеленні достовірно впливала на рівень молочної продуктивності за першу лактацію. На живу масу, як фактор, що визначав рівень молочної продуктивності, припадало 8,5-8,7\%.

При зростанні живої маси корів-первісток від менше ніж 400 кг до більше ніж 550 кг надій за першу лактацію зростав на 23\%. Причому, тварини, які мали живу масу понад 500 кг достовірно переважали за надоєм корів 3 меншою живою масою. За вмістом жиру та білка в молоці перевагу мали тварини 3 живою масою понад 450 кг (табл. 9).

\section{Таблиця 7}

Вплив паратипових факторів на рівень молочної продуктивності

\begin{tabular}{cccc}
\hline Паратипові фактори & \multicolumn{3}{c}{ Показники продуктивності } \\
\cline { 2 - 4 } Сезон першого отелення & Надій & Кількість молочного жиру & Кількість молочного білка \\
Жива маса при першому & $1,4^{*}$ & І лактація & 0,9 \\
отеленні & & 1,1 & $8,7^{* * *}$ \\
& $8,5^{* * *}$ & І лактація & $8,7^{* * *}$ \\
Господарство & $16,4^{* * *}$ & І лактація & $15,7^{* * *}$ \\
& $27,7^{* * *}$ & ІІІ лактація & $21,1^{* * *}$ \\
& $2,9^{*}$ & $31,8^{* * *}$ & $3,0^{*}$ \\
\hline
\end{tabular}

\section{Таблиця 8}

Залежність молочної продуктивності від сезону першого отелення

\begin{tabular}{|c|c|c|c|c|c|c|}
\hline \multirow[b]{2}{*}{ Сезон отелення } & \multicolumn{3}{|c|}{ I лактація } & \multicolumn{3}{|c|}{ III лактація } \\
\hline & надій, кг & $\begin{array}{l}\text { кількість моло- } \\
\text { чного жиру, кг }\end{array}$ & $\begin{array}{l}\text { кількість моло- } \\
\text { чного білка, кг }\end{array}$ & надій, кг & $\begin{array}{l}\text { кількість моло- } \\
\text { чного жиру, кг }\end{array}$ & $\begin{array}{c}\text { кількість молоч- } \\
\text { ного білка, кг }\end{array}$ \\
\hline Весна $(\mathrm{n}=157)$ & $3582 \pm 77,2$ & $139,4 \pm 3,1$ & $114,1 \pm 2,2$ & $4363 \pm 154,9$ & $173,2 \pm 6,0$ & $137,4 \pm 4,9$ \\
\hline Зима $(\mathrm{n}=164)$ & $3840 \pm 52,6$ & $150,0 \pm 2,9$ & $119,6 \pm 2,1$ & $4485 \pm 191,7$ & $177,4 \pm 8,0$ & $137,1 \pm 5,9$ \\
\hline Літо $(n=229)$ & $3586 \pm 52,6$ & $143,2 \pm 2,2$ & $113,6 \pm 1,2$ & $4537 \pm 114$ & $176,9 \pm 4,8$ & $141,4 \pm 3,6$ \\
\hline Осінь $(n=119)$ & $3686 \pm 77,8$ & $145,7 \pm 3,1$ & $114,9 \pm 2,5$ & $4594 \pm 146,4$ & $182,4 \pm 6,1$ & $140,7 \pm 4,4$ \\
\hline
\end{tabular}

Таблиця 9

Залежність молочної продуктивності від живої маси при першому отеленні

\begin{tabular}{lccc}
\hline \multicolumn{1}{c}{ Градація живої маси, кг } & \multicolumn{3}{c}{ І лактація } \\
\cline { 2 - 4 } & надій, кг & кількість молочного жиру, кг & кількість молочного білка, кг \\
\hline менше 400 $(\mathrm{n}=13)$ & $3082 \pm 141,3$ & $119,1 \pm 5,8$ & $94,7 \pm 4,3$ \\
від 401 до 450 (n=62) & $3251 \pm 88,6$ & $127,2 \pm 3,6$ & $101,8 \pm 3,0$ \\
від 451 до 500 (n=129) & $3580 \pm 59,6$ & $142,1 \pm 2,5$ & $112,1 \pm 2,0$ \\
від 501 до 551 (n= 74) & $3787 \pm 85,1$ & $150,3 \pm 3,6$ & $120,0 \pm 2,8$ \\
більше 550 $(\mathrm{n}=27)$ & $3767 \pm 166,3$ & $145,7 \pm 7,0$ & $117,5 \pm 5,4$ \\
\hline
\end{tabular}

Умови утримання та годівлі в господарстві суттєво впливали на рівень молочної продуктивності за першу, третю та кращу лактації. Найкращим надоєм відрізнялися тварини господарства ТОВ АФ "Вікторія". Вони достовірно переважали корів з ДП БФ “Укрлік- трави” та ДП ДГ ІСГПС НААН за всіма дослідженими лактаціями, причому за першу та третю різниця була достовірною. За кількістю молочного жиру та білка в молоці спостерігалася подібна тенденція (табл. 10).

\section{Таблиця 10}

Вплив господарства на рівень молочної продуктивності

\begin{tabular}{|c|c|c|c|c|c|c|}
\hline \multirow[b]{2}{*}{ Господарство } & \multicolumn{3}{|c|}{ I лактація } & \multicolumn{3}{|c|}{ III лактація } \\
\hline & надій, кг & $\begin{array}{c}\text { кількість молоч- } \\
\text { ного жиру, кг }\end{array}$ & $\begin{array}{c}\text { кількість молоч- } \\
\text { ного білка, кг }\end{array}$ & надій, кг & $\begin{array}{l}\text { кількість моло- } \\
\text { чного жиру, кг }\end{array}$ & $\begin{array}{c}\text { кількість молоч- } \\
\text { ного білка, кг }\end{array}$ \\
\hline $\begin{array}{l}\text { ДП БФ “Укрліктрави” } \\
(\mathrm{n}=542)\end{array}$ & $3614 \pm 35,1$ & $143,6 \pm 1,5$ & $115,7 \pm 1,1$ & $4481 \pm 74,3$ & $176,9 \pm 3,0$ & $142,0 \pm 2,4$ \\
\hline $\begin{array}{l}\text { ООО АФ "Вікторія" } \\
(\mathrm{n}=40)\end{array}$ & $5016 \pm 132,3$ & $195,0 \pm 5,0$ & $147,6 \pm 4,9$ & $5672 \pm 206,0$ & $228,9 \pm 7,7$ & $166,8 \pm 7,7$ \\
\hline $\begin{array}{l}\text { ДП ДГ ІСГПС НААН } \\
(\mathrm{n}=86)\end{array}$ & $3343 \pm 77,8$ & $125,4 \pm 2,8$ & $104,3 \pm 22,3$ & $3479 \pm 155,3$ & $131,9 \pm 6,9$ & $106,7 \pm 4,9$ \\
\hline
\end{tabular}


Важливим є питання, як впливають умови утримання на показники тривалості використання та довічної продуктивності корів. Саме обрана технологія утримання тварин, умови годівлі суттєво впливають на прижиттєву продуктивність тварин та час, який тварини утримуються в господарстві. В результаті наших досліджень встановлено, що показники тривалості використання та довічної продуктивності корів, які утримувалися в різних господарствах суттєво відрізняються. За тривалістю життя та господарського використання тварини, які утримуються в ДП ДГ ІСГПС НААН достовірно (Р < 0,001) переважають корів з господарства БФ ДП “Укрлактрави”. Відповідно, і за коефіцієнтом господарського використання перевага була на їх боці $(\mathrm{P}<0,001)$ (табл. 11).

\section{Таблиця 11}

Показники тривалості використання та довічної продуктивності корів залежно від господарства, $\mathrm{M} \pm \mathrm{m}$

\begin{tabular}{lcc}
\hline \multicolumn{1}{c}{ Показники } & ДП ДГ ІСГПС НААН & БФ ДП «Укрліктрави» \\
\hline Враховано голів & 119 & 691 \\
Тривалість, днів & $3015,2 \pm 107,8^{* *}$ & $1977,1 \pm 20,0$ \\
життя & $1982,4 \pm 113,0^{*}$ & $874,9 \pm 18,8$ \\
господарського використання & $60,0 \pm 0,01$ & $41,5 \pm 0,5$ \\
Коефіцієнт господарського використання & $18670,9 \pm 1294,9^{* *}$ & $9623 \pm 225$ \\
Довічна продуктивність: & $3,77 \pm 0,04$ & $3,41 \pm 0,02$ \\
надій, кг & $6,0 \pm 0,32^{* *}$ & $4,6 \pm 0,1$ \\
жир, \% & $9,2 \pm 0,32$ & $11,0 \pm 0,1^{* *}$ \\
Надій за 1 день, кг: & & \\
життя & & \\
\hline
\end{tabular}

За довічною продуктивністю корів перевагу також мали тварини, яких утримують у ДП ДГ ІСГПС НААН (на 94\%) (Р < 0,001). При цьому надій за один день життя був більшим на $22 \%(\mathrm{P}<0,05)$ у тварин дослідного господарства, а за один день господарського використання - у тварин БФ ДП “Укрліктрави” - на 19\% (Р < 0,01), що пояснюється їх вищою молочною продуктивністю за лактацію.

Результати наших досліджень підтверджують висновки, які роблять інші дослідники. Так, раніше проведені дослідження щодо впливу умовної кровності на молочну продуктивність (Радченко Н.П., 2006), вказують на те, що використання генетичного матеріалу швіцької породи на лебединській худобі дозволяє підвищити іiі генетичний потенціал. Надій за першу лактацію серед лебединських корів був найнижчим. Надій тварин певною мірою залежав від генотипу. Вірогідну різницю з контрольною групою мали корови 3 часткою крові швіцької породи 3,1-75\% + 297 і 532 кг $(\mathrm{P}>0,99)$.

Найгірші за цим показником були корови 3 найбільшим відсотком крові швіцької породи 75,1-96,9\%. Результати наших досліджень вказують на те, що сила впливу умовної кровності за швіцькою породою на надій складає - за першу лактацію $3,1 \%$, за третю 8,2\%. Подібні результати наводять і інші науковці. Салогуб A.M. (Salohub, 2001), який робить висновок, що кращі показники надою отримані від корів із найнижчою часткою спадковості за швіцькою породою. У групах тварин з кровністю до 50,0\% та від 50,01 до $62,5 \%$ середній надій за першу лактацію відповідно становив - 3888 і 3806 кг молока, другу - 4610 і 4511 та третю - 5267 і 5280 кг. У групі помісних корів 3 найвищою спадковістю за швіцькою породою $(87,51$ і більше \%) надій за першу лактацію становив 3378 кг молока. Різниця у порівнянні з однолітками помісних груп корів з кровністю за поліпшуючою породою у межах від 50,0\% і до $87,5 \%$ становила $249-510$ кг $(\mathrm{P}<0,05-0,001)$.

Водночас, існують дані, що за рівнем надою виявлена тенденція росту показника 3 підвищенням частки крові поліпшуючої породи, різниця склала 218 кг без статистичного підтверження вірогідності. Група корів 3 найбільшою часткою швіцької крові має перевагу над іншими за середнім вмістом жиру (від +0.02 до $+0.03 \%$ ) та білка в молоці (від +0.11 до $+0.20 \%$ ) (Ladyka, 1999).

Вчені (Gill, 2008; Bolhova, 2009) роблять висновки, які в певній мірі співпадають 3 результатами наших досліджень, а саме - істотний та, у більшості випадків, достовірний вплив чинять: із паратипових факторів - роки народження та першого отелення; із генотипових - умовна кровність за поліпшуючою породою, племінна цінність батька, лінія батька, селекційні та індекси племінної цінності матері, батька, батька матері, матері батька та батька батька.

Дослідники наводять дані, що бугаї-плідники найбільше впливають на продуктивні показники корів (Prykhodko, 2009), що підтверджується і результатами наших досліджень. Сила впливу батька на показники молочної продуктивності складає понад 20\%, а на довічний надій - $17 \%$.

Науковці зазначають, що умовна кровність за поліпшуючою породою впливає на довічний надій, тривалість господарського використання, середній надій на один день життя та господарського використання (Polupan, 2014). Такі висновки підтверджуються i результатами наших досліджень.

\section{Висновки}

В результаті проведених досліджень нами встановлено, що тварини української бурої молочної породи мають достатній рівень молочної продуктивності. На 
надій за першу, третю та найкращу лактації достовірний вплив мають генотипові та паратипові фактори. Умовна кровність за швіцькою породою, лінійна належність та походження за батьком впливали на надій за лактацію, вміст жиру в молоці та показники тривалості використання та довічної продуктивності корів. Сила впливу умовної кровності знаходиться в межах $0,8-8,2 \%$, лінійної належності - 0,3-4,5\%, походження за батьком - 5,7-38,6\%. Паратипові фактори також впливають на показники молочної продуктивності та тривалості використання та довічної продуктивності корів. На сезон першого отелення, як фактор, що визначає молочну продуктивність припадає $0,9-1,4 \%$, на живу масу при першому отеленні - 8,5-8,7\%, на господарство, в якому утримуються тварини - 2,9-31,8\%. Наявність достовірного впливу генотипових та паратипових факторів на молочну продуктивність тварин i тривалість довічного використання та довічної продуктивності корів, дає змогу покращити їх селекційними та технологічними заходами.

Перспективи подальших досліджень нами вбачаються у вивченні технологічних властивостей молока корів української бурої молочної породи.

\section{References}

Babii, N.M. (2008). Hospodarsko-biolohichni osoblyvosti chorno-riaboi khudoby vitchyznianoi ta zarubizhnoi selektsii $\mathrm{v}$ umovakh zakhidnoho rehionu Ukrainy: avtoreferat dys. na zdobuttya stupenya k. s.-g. n.: 06.02.01. Economical and biological peculiarities of Black-and-White cattle of domestic and foreign selection in the conditions of Western Ukraine. Chubynske, 20 (in Ukrainian).

Boiko, Yu.M. (2012). Otsinka efektyvnosti formuvannia henealohichnoi struktury ukrainskoi buroi molochnoi porody: avtoreferat dys. na zdobuttya stupenya k.s.g.n. za spetsial'nistyu 06.02.01. - Ukrainian Brown Dairy breed genealogical structure forming efficiency estimation. Chubynske, 21 (in Ukrainian).

Bolhova, N.V. (2009). Selektsiino-henetychna otsinka promizhnykh henotypiv ukrainskoi buroi molochnoi porody, shcho stvoriuietsia: avtoreferat dys. na zdobuttya stupenya k. $\quad$ s.-g. n. za spetsial'nistyu 06.02.01. Plant-breeding-genetic estimation of intermediate genotypes by the Ukrainian borax of suckling breed which is created. Chubynske, 22 (in Ukrainian).

Bratushka, R.V. (2013). Vplyv henetychnykh i paratypovykh faktoriv na formuvannia selektsiinykh oznak tvaryn sumskoho vnutrishnoporodnoho typu ukrainskoi chorno-riaboi molochnoi porody : avtoreferat dys. na zdobuttya stupenya k. s.-g. n. za spetsial'nistyu 06.02.01. Influence of genetic and paratypic factors on the formation of selection traits of Sumy interbreed type of the Ukrainian Black-andWhite Dairy breed. Chubynske, 19 (in Ukrainian).

Gill, M.I. (2008). Henetychnyy analiz polihenno obumovlenykh ta polimorfnykh oznak khudoby molochnykh porid - Genetic analysis of polygenic and polymorphic traits caused cattle dairy breeds. Chubyns'ke (in Ukrainian).
Denysyuk, O.V. (2015). Vplyv intensyvnosti formuvannya zhyvoyi masy na molochnu produktyvnist' koriv The influence of intensity formation of live weight on milk production of cows. Rozvedennya i henetyka tvaryn. Mizhvidomchyy tematychnyy naukovyy zbirnyk, 49, 80-85 (in Ukrainian).

Kovalenko, V.V. (2013). Zviazok intensyvnosti naroshchuvannia laktatsiinoi kryvoi z molochnoiu produkty-vnistiu koriv ukrainskoi chervonoi molochnoi porody. Visnyk ahrarnoi nauky Prychornomoria, 4(76), 2, 81-89. http://dspace.mnau.edu.ua/ jspui/handle/123456789/1481 (in Ukrainian).

Ladyka, V.I. (1999). Selektsiini aspekty yakisnoho udoskonalennia populiatsii lebedynskoi khudo-by : avtoreferat dys. na zdobuttya stupenya d. s.-g. n. za spetsial'nistyu 06.02.01. Seiektion aspects qualitative perfection popuiation of Lebedyn Breed. Chubynske, 32 (in Ukrainian).

Lytvynenko, T.V. (2010). Vikovi zminy intensyvnosti rostu remontnykh telyts' holshtyns'koyi porody. Visnyk Sums'koho NAU. Seriya - Tvarynnytstvo, 12(18), 73-75 (in Ukrainian).

Lobodna, V.P. (2014). Otsinka efektyvnosti selektsiinoho udoskonalennia stada ukrainskoi chervono-riaboi molochnoi porody : avtoreferat dys. na zdobuttya stupenya k. s.-g. n. za spetsial'nistyu 06.02.01. Estimation to efficiency of plant-breeding improvement of herd of the Ukrainian red-and-whate dairy breed. Chubynske, 21 (in Ukrainian).

Polupan, Yu.P. (2014). Efektyvnist dovichnoho vykorystannia koriv riznykh krain selektsii. Visnyk Sumskoho NAU. Seriia "Tvarynnytstvo", 2/2(25), 14-20. http://nbuv.gov.ua/UJRN/Vsna_tvar_2014_2\%282\%29_ 4 (in Ukrainian).

Prykhodko, M.F. (2009). Otsinka produktyvnosti ta tekhnolohichnykh vlastyvostei moloka novostvorenykh porid i typiv khudoby pivnichnoskhidnoho rehionu Ukrainy: avtoreferat dys. na zdobuttya stupenya k. s.-g. n. za spetsial'nistyu 06.02.04. Estimation of productivity and technological properties of milk of newly developed livestock breeds and types in the north-eastern region of Ukraine. Kherson, 21 (in Ukrainian).

Salohub, A.M. (2001). Selektsiino-henetychni aspekty formuvannia skotarstva pivnichno-skhidnoho rehionu Ukrainy: avtoreferat dys. na zdobuttya stupenya d. s.g. n. za spetsial'nistyu 06.02.04. Selective and genetic aspects of cattle formation in the North-eastern region of Ukraine. Kharkiv, 36 (in Ukrainian).

Trotsenko, Z.H. (2010). Vplyv tempiv rozvytku remontnykh telyts ukrainskoi chorno-riaboi molochnoi porody na molochnu produktyvnist koriv-pervistok. Visnyk Poltavskoi derzhavnoi ahrarnoi akademii, 2, 79-81. https://www.pdaa.edu.ua/sites/default/files/visnyk/2010/0 2/79.pdf (in Ukrainian).

Tulinova, O.V., Vasi'teva, E.N., Egiazarjan, A.V., \& Solovej, V.B. (2011). Molochnaja produktivnost' ajrshirskih pervotelok $\mathrm{v}$ zavisimosti ot intensivnosti ih rosta $\mathrm{v}$ raznye periody vyrashhivanija. Zootehnija, 8, 2-4 http://naukarus.com/molochnaya-produktivnostayrshirskih-pervotelok-v-zavisimosti-ot-intensivnosti-ihrosta-v-raznye-periody-vyraschivaniya (in Russian). 
Khmelnychyi, L.M. (2012). Otsinka rostu ta rozvytku telyts ukrainskoi chervono-riaboi molochnoi po-rody za vykorystannia vahovykh ta liniinykh parametriv. Visnyk Sumskoho NAU. Seriia -Tvarynnytstvo, 12(21), 18-21. http://nbuv.gov.ua/UJRN/Vsna_tvar_2012_12_7 (in Ukrainian).

Shevchenko, A.P. (2013). Selektsiino-henetychni parametry otsinky tvaryn sumskoho vnutrishnoporodnoho typu ukrainskoi chorno-riaboi molochnoi porody: avtoreferat dys. na zdobuttya stupenya k. s.-g. n. za spetsial'nistyu 06.02.04. Selective and genetic features of animals of Sumy into a pedigree type of the Ukrainian black-and-white dairy breed. Kharkiv, 22 (in Ukrainian).

De Vries, A. (2013). Cow longevity economics: The cost benefit of keeping the cow in the herd. Cow Longevity Conference, 22-52. http://www.delaval.com.mx/en//Dairy-knowledge-and-advice/Cow-

Longevity/Scientists-view-on-cow-longevity/Cowlongevity-economics---the-cost-benefit-of-keepingthe-cow-in-the-herd/

Effa, K., Hunde, D., Shumiye, M., \& Silasie, R.H. (2013). Analysis of longevity traits and lifetime productivity of crossbred dairy cows in the Tropical Highlands of Ethiopia. Journal of Cell and Animal Biology, 7(11), 138-143. doi: 10.5897/JCAB2013.0375.

De Vries, A. (2017). Economic trade-offs between genetic improvement and longevity in dairy cattle. Journal of Dairy Science, 100(6), 4184-4192. doi: 10.3168/jds.2016-11847.

Gaidarska, V., Stoikov, P., Ivanova, T., \& Harizanova, C. (2010). The future of dairy cattle and development of dairy cattle breeding in world. Zhivotnovodnye nauki - Livestock science, 1, 219-226.

Gajdarska, V. (2015). Molochnoe skotovodstvo - Dairy cattle breeding. Institut zhivotnovodnyh nauk. Kostinbrod (in Bulgarian).

Tsuruta, S.D., Lourenco, A.L., Misztal, I., \& Lawlor, T.J. (2017). Genomic analysis of cowmortality and milk production using a threshold-linear model. Journal of
Dairy Science, 100(9), 7295-7305. doi: 10.3168/jds.2017-12665.

Hutchison, J.L., VanRaden, P.M., Null, D.J., Cole, J.B., \& Bickhart, D.M. (2017). Genomicevaluation of age at first calving. Journal of Dairy Science, 100(8), 6853-6861. doi: 10.3168/jds.2016-12060.

VandeHaar, M.J., Armentano, L.E., Weigel, K., Spurlock, D.M., Tempelman, R.J., \& Veerkamp, R. (2016). Harnessing the genetics of the modern dairy cow to continue improvements in feed efficiency. Journal of Dairy Science, 99(6), 4941-4954. doi: 10.3168/jds.201510352.

Compton, C.W.R., Heuer, C., Thomsen, P.T., Carpenter, T.E., Phyn, C.V.C., \& McDougal, S. (2016). Invited review: A systematic literature review and metaanalysis of mortality and culling in dairy cattle. Journal of Dairy Science, 100(1), 1-16. doi: 10.3168/jds.2016-11302.

https:/www.ncbi.nlm.nih.gov/pubmed/28341041.

Lucy, M.C. (2000). Reproductive Loss in High-Producing Dairy Cattle: Were Will it End. J. Dairy sci., 84, 12771293. https://www.ncbi.nlm.nih.gov/pubmed/11417685.

Martens, H., \& Bange, Chr. (2013). Longevity of high producing dairy cows: a case study. Lohmann Information, 48(1), 53-57. http://lohmanninformation.de/content/1_i_48_artikel7.pdf.

Murray, B. (2013). Finding the fools to achieve longevity in Canadian dairy cows. WCDS Advances in Dairy Technology, 25, 15-28.

Milostiviy, R.V., Kalinichenko, O.O., Vasilenko, T.O., Milostiva, D.F., \& Gutsulyak, G.S. (2017). Problematic issues of adaptation of cows of golshtinskaya breed in the conditions of industrial technology of milk production. Scientific Messenger LNUVMBT named after S.Z. Gzhytskyj, 19(73), 28-32. doi: 10.15421/nvlvet7306.

Chebel, R.C., Silva, P.R.B., Endres, M.I., Ballou, M.A., \& Luchterhand, K.L. (2016). Social stressors and their effects on immunity and health of periparturient dairy cows. Journal of Dairy Science, 99(4), 3217-3228. doi: 10.3168/jds.2015-10369. 